\title{
On Necessity of Property Rights Transformation of Traditional Clothing
}

\section{Tang Jing}

\author{
Chongqing Business Vocational College, Chongqing, 401331
}

\begin{abstract}
Keywords: Clothing industry; Traditional clothing; Cultural property rights; Property
\end{abstract}
\begin{abstract}
With the acceleration of economic globalization, large quantities of the international brands have entered the domestic market, and quickly occupied the domestic high-end market, and this to some extent has endangered the development of the domestic clothing industry. However, how to develop the domestic clothing brand? This series of problems have brought us to trace the source to think about the Chinese traditional clothing. In face of the status quo that China's traditional clothing has gradually become the publically funded, it's necessary to pay attention to it with in-depth study. This thesis is mainly to review the traditional clothing, and analyze the necessity for property rights transformation of traditional clothing culture through the analysis of status of clothing industry in China, and explore the way to achieve its transformation.

Since the accession to the WTO, China's clothing industry has had the earth-shaking changes and rapid development under the strong driving force in the domestic and foreign markets, the rapid development. Of which, the world's economic integration has also become the important factors and core strength for the re-transformation and upgrading of China's clothing industry. The current domestic situation is that China has the first production of clothing products in the world. Meanwhile, China is the world's largest exporter of clothing products, and even is the country with the largest clothing consumer. According to current situation, although China has accounted for a very large advantage, and it can be called as the clothing "manufacturing power", China extremely lacks the independent brands, and so China is considered as a "small brand country."

First of all, China's clothing brand is very scattered compared with that in foreign market, China lacks the world-renowned brands. Because China's product is with relatively low technology content, and there's insufficient innovation, so that the brands in China lack the competitiveness in the international market. In this regard, China only wins in quantity, but it's urgent to solve the problem of quality. Second, the clothing marketing strategy in China is relatively backward, which still relies mainly on cheap labor, this is a large gap compared with the clothing industry in foreign countries.

The overall level of clothing industry is not high from design to marketing, and the market depends mainly on middle-end and low-end products. The OEM-based, middle-end and low-end products are mostly used as export methods, there are few high-end products. In addition, although there are a large number of the clothingenterprises in China, most of them are small enterprises with low grade, and many small and medium enterprises are relatively backward in business management, brand culture, production mode, transportation and logistics and other aspects, it is difficult to resist the strong competition from the international market. It's difficult to form a strong competitiveness if the above ability can't be improved. Therefore, the clothing industry in China must face the current situation and study from foreign countries to grow and develop.
\end{abstract}




\section{Development situation of clothing industry in China}

First of all, there are still very few domestic brands in the domestic high-end market, this also shows that China's brand competitiveness is poor, there's low ability in product design innovation and low technological content, China is just a country for garment production and processing, rather than a clothing design power. Second, China is weak in clothing design ability and marketing, its market competition relies too much on low labor costs, there's still a considerable gap for China compared with the foreign garment industry. The overall level of clothing industry is not high, middle-end and low-end products have accounted for a large proportion, while there's a small proportion for high value-added products.

There's earlier emergence and development offoreign clothing industry, and there are now a large number of well-known foreign clothing brands steadily standing in the international clothing market. The development of foreign advanced technology makes its clothing product design level to be high in good quality, resulting in the emergence of a large number of international top fashion designers. These designers have occupied and stabilized the leading position of the international clothing market. The rise of modern garment industry in China is late, and there's only a short history of a few decades for the development. It is difficult to form a unique product style, and difficult to be fully accepted by the international public.

There's the late rise of China's modern garment industry, with only a shorty history of the development for a few decades, and China's clothing design level is far behind the international level, there's yet no clothing designer with world's influential fashion designer. But also a lot of them are the imitation and copy of things from Europe and the United States, which has not fully carry forward the characteristics of Chinese nation itself, it's difficult to form a unique product style. Low labor force, and low product technology contentmake China become the garment processing base of the United States, Japan and other developed countries. Weak design level and innovation ability, the lack of new varieties of clothing fabrics determines that the country does not have the ability to lead the fashion and the trend, China is not fully recognized and accepted by the international public. Under the WTO rules, the Chinese market will become a part of the international market, and the domestic clothing enterprises can fully enjoy advanced technology and broad market developed countries, developed countries can also take full advantage of China's quality and cheap resources. But at present, some of the world's regional economic protection bodies formed in the world to a certain extent has hindered the clothing export of China. Such kind of the regional economy like the EU and the North American Free Trade Area is growing, and the clothing exports in China are placed in the unequal trade status. This makes us have to pay attention to the development of our own clothing brand, and be suitable for the requirements of the international clothing market, which is the only way to maintain a place in the clothing industry with fierce competition.

Since the clothing industry in China can't guide the trend, it's inevitable that China imitates refining step to step by following the foreign trend. The rich cultural heritage contained in China's traditional clothingcan be the most representative clothing of the Chinese characteristics. Only the focus on the development of the traditional clothing in the domestic clothing market can China be based on its own brand to compete with foreign clothing brands, thus to squeeze into the international clothing market to lead the trend. But "national characteristics" not refer to be simply in the clothing itself, which is more performance in the design concept of five thousand years of Chinese culture as the background. Paying attention to the development of the traditional clothing has become the inevitable trend of development of China's clothing industry, which plays a pivotal role in the development of the entire domestic clothing industry. 
In addition, due to the spread of the international financial crisis to the real economy and worldwide, the external environment faced by China's clothing industry in 2009 was more severe. At the same time, as a result of the financial crisis, there's the momentum that a large number of the foreign clothing enterprises develop towards Chinese clothing market, which has a greater impact on China's clothing industry, the competition in the clothing market will be more incentive. The clothing market competition is also the brand competition, it's essential to have a number of brands with the national characteristics, thus to stand out in the strong competition, and take a firm foothold. But "national characteristics" not simply refer to the clothing itself, but consider the design concept as the background of the five thousand years of Chinese culture.It should be stressed that the traditional culture is the soil for the survival of all ethnic groups, only the design is conducted according to the localization can the brilliant work be designed accordingly. As the product of the national culture, only by taking the traditional culture of the ancient Chinese as the source for the design, to create the modern fashionable dress with the condensation of charm and spiritual style of Chinese charm, thus to promote brilliant Chinese clothing to be out of the country, and enter to the world's hall of the modern fashion. Only by letting the world see more about outstanding traditional culture in China from the contemporary dress of our nation, China's traditional clothing can really become the world. The traditional clothing is the product made through the perfect combination of the traditional national culture and clothing. Attention to the development of the traditional clothing has become the inevitable trend of the development of China's clothing industry, which has played a pivotal role in the development of the entire domestic clothing industry.

\section{Development of traditional clothing in China}

Culture is a process from the brutal to the civilization, which is the phenomenon to reflect the human thought and activity, there are people on earth, and then there's the culture on it. Traditional clothing has passed the Chinese culture for thousands of years, and it is not only the clothing performance of a period of time, but alsois more representative of unique culture, unique style of the period. With the development of the economy, modern elements occupy the mainstream of the clothing industry, which has become a trend to be chased by the new generation. Fashion and popular has become the characteristics of the modern clothing. To a certain extent, the traditional clothing is obscured by modern civilization. It's nearly difficult to see the traditional clothing shadow in major shopping malls. This cannot help us but think us: Whether the traditional dress is just a symbol of the times, belonging only to the last century, and the people of that era.

With the economic development, modern elements have occupied the mainstream of the clothing industry, which has become the trend to be chased by a new generation. Fashion, and popular have become the characteristics of the modern clothing. The culture is, to a certain extent, obscured by modern civilization. In major shopping malls, it's almost difficult to see the shadow of the traditional clothing. This makes us to think: Whether the traditional clothing is just a symbol of the times, belonging only to the last century,and those people of that era. Over time, with the departure of the old generation of people wearingtraditional clothing, the traditional clothing will eventually become a museum exhibit, and a history. But the traditional clothing itself is theperformance of the integration of the culture, socio-economy and lifestyle, which is in the organic state of survival, and this survival state contains a self-renewal mechanism.The development of culture should be people-oriented, with the change of the concept, the culture needs innovation, in other words, the traditional clothing design will achieve its surpassing on the basis of maintaining their own style. But now a lot of people have misinterpreted the innovation, and they 
believe that "the great men of the past cannot be seen, and those cannot be seen in future years" is innovation. It should be said that innovation is the continuation and development of tradition. The creation of a modern costume with the nationality is not only to pursue the ingenuity of modeling, patterns and decorative craft in the form, more importantly it is the reflection in the connotation and taste. As the Russian writer Gogol said: "The real nationality is not to describe the sleeveless gown of the peasant woman, but the spirit of the nation."

China is a civilized country with five thousand years of history. Traditional clothing has delivered the precipitation of culture in China for five thousand years. It is a unique quality of the nation that can only be cultivated from the soil of the national art. From ancient times to pre-Qin, from pre-Qin to Ming and Qing Dynasties, clothing culture has inherited the historical changes, and followed the pace of the times with a long history. The clothing form of each period is ever-changing, which has its unique style, the Qin and Han's clothing was concise and generous, the clothing in Tang Dynasty was romantic and elegant, the clothing in Song Dynasty was elegant and quiet, and the clothing in Ming Dynasty was simple and dignified and so on. However, in modern times, with China's gradual development to the world and modern civilization, it's found that China has been in the space with a serious lack of the national characteristics. It's essential to continue to call for return of the national consciousness, continuing to seek the development of traditional clothing culture. But after decades of efforts, today the "tradition" showed in our vision is still a replica of the clothing in Qing Dynasty, the traditional has long been in subversion, the use of the traditional clothing is also only seen in the corner of folk festivals and wedding ceremonies. The characteristics of traditional clothing culture need to be re-examined and a new definition should be made, the innovation of the era must be found for the development of traditional clothing culture. The realization of the transformation of the traditional clothing property rights has not only pointed out a new direction for its development, but also the mission given by the times. The manufacturing, production, control, income, and others of the traditional clothing are only the unique rights of China's descendants. People who do not belong to the nation cannot use it at will. In order to protect this unique right from infringement, it is necessary for us to make this right to be more clear and definite, namely to convert property rights transformation of the traditional clothing. At present, the best way to protect the traditional clothing culture is to make the traditional clothing culture intellectual to be with property rights. As a result, a batch of Chinese traditional clothing has been approved as a national intangible cultural heritage, and the number of approvals has been gradually increased.

\section{Exploration on the way for property rights transformation of traditional clothing culture}

To some extent, the traditional clothing culture belongs to folklore of the intangible cultural heritage, and the intangibleculture heritage itself is protected by intellectual property rights. Traditional clothing property rights refer to a kind of special property owned by the heir of the intangible cultural heritage or owner as the owner of its traditional clothing culture. It is the rights damaged or benefited caused by the owners due to the use of the owned traditional clothing culture "property"within conditions of the national laws and regulations, which is the behavioral rights of traditional clothing owner within the limits of the right. The traditional clothing property rights are to give corresponding right under the premise of recognizing non- homogeneity of capital and emphasizing the important position of the traditional clothing in the production practices. Simply, the property rights of traditional clothing are the process of realizing traditional clothing culture into the process ofintangible cultural heritage. 
The study of the property rights of the traditional clothing culture do not mean that any traditional clothing must be with property rights. China's property rights should be conducted by following the principle of "who made, who owns the property rights".In the definition process, it is necessary to protect not only the legitimate rights and interests of property owners and the business users, but also ensure that the legitimate rights and interests of other property owners won't be infringed.

The property rights of a series interests formed after the property rights are owned by the collective ownership. For theinterests of owners formed by the collective through the use of the investment of the traditional clothing in the collective enterprises, the property rights belong to collective ownership of labors within the collective. The income obtained by other enterprises, collectives or individuals by using traditional clothing of the collective for commodity management, its profit income, ownership of the property are owned by the collective.For collective traditional clothing property rights obtained by other organizations, groups or individuals through improper means, the property rights are still owned by the collective after the collective prosecution.

\section{Exploration on the method and way of realizing its property rights}

The traditional clothing itself is a form of naked cultural expression, and is also the product of historical legacy, which in itself does not give any power to descendants. Through the analysis of the above content, the author has realized the need to achieve transformation of the traditional clothing property rights. In this regard, the author further explores the methods and ways torealize its transformation of property rights.

Due to a large number of objects for intellectual property protection, the realization of the transformation of the traditional clothing of intellectual property determines that there's the diversity and uncertainty of methods and ways for the transformation of the property rights. The following ways can be considered as references:

First is to convert into a patent through transformation, for the traditional clothing, it's mainly to protect through the external design. The patent is obtained by the approval of specific state administrative organs, which are mainly about the approval of the national intellectual property rights.

Second is to convert into a trade secret for protection, this is mainly about thebusiness secret protection for production, processing technology, processes, and others of the traditional clothing. The right owners take their own confidential measures to obtain and maintain the property rights.

Third is to protect as a trademark to enjoy the exclusive right to use the trademark. This is mainly about the trademark use of graphic design, lines, signs, and others of the traditional clothing in line with the trademark characteristics. This is obtained through the approval of specific state administrative organs, and is mainly approved by the trademark authorities of the State Administration for Industry and Commerce.

Fourth is to protect through the transformation into copyright, thus to protect the expression form of the unique national culture contained by the traditional clothing, which will be obtained automatically since the date of the completion of the results.

Fifth is to consider legislation, there should be the development of special Intangible Cultural Heritage Protection Law to protect the traditional clothing. The special department of the state administrative organs should be established to deal with the approval. 


\section{References}

[1] Meng Shaoni: "Chinese traditional dress culture and development prospects", "Journal of Nanyang Teachers College" 2009 年 04 期.

[2] Xiaoting: "Chinese traditional clothing - cheongsam", "China Fiber Inspection" 200901 period.

[3] "2009 China Garment Industry Research Advisory Report", published in March 200926. 